\title{
A GLOSSARY OF CORPUS LINGUISTICS
}




\section{TITLES IN THE SERIES INCLUDE}

Peter Trudgill

A Glossary of Sociolinguistics

0748616233

Jean Aitchison

A Glossary of Language and Mind

0748618244

Laurie Bauer

A Glossary of Morphology

0748618538

Alan Davies

A Glossary of Applied Linguistics

0748618546

Geoffrey Leech

A Glossary of English Grammar

0748617299

Alan Cruse

A Glossary of Semantics and Pragmatics

0748621113

Philip Carr

A Glossary of Phonology

0748622349

Vyvyan Evans

A Glossary of Cognitive Linguistics

0748622802

Mauricio J. Mixco and Lyle Campbell

A Glossary of Historical Linguistics

0748623795 


\section{A Glossary of Corpus Linguistics}

\section{Paul Baker, Andrew Hardie and Tony McEnery}

Edinburgh University Press 
(C) Paul Baker, Andrew Hardie and Tony McEnery, 2006

Edinburgh University Press Ltd

22 George Square, Edinburgh

Typeset in Sabon

by Norman Tilley Graphics, Northampton, and printed and bound in Finland by WS Bookwell

A CIP record for this book is available from the British Library

ISBN-10 0748624031 (hardback)

ISBN-13978 0748624034

ISBN-10 0748620184 (paperback)

ISBN-139780 748620180

The right of Paul Baker, Andrew Hardie and Tony McEnery to be identified as authors of this work has been asserted in accordance with the

Copyright, Designs and Patents Act 1988.

Published with the support of the Edinburgh University Scholarly Publishing Initiatives Fund 